九州大学学術情報リポジトリ

Kyushu University Institutional Repository

\title{
Effect of Nitrogenous Forms on Immobilization and Release of Nitrogen in Soil
}

Ahmad, Ziaudd in

Laboratory of Soil Fertility and Plant Nutrition, Faculty of Agriculture, Kyushu University

Kai, Hideaki

Laboratory of Soil Fertility and Plant Nutrition, Faculty of Agriculture, Kyushu University

Harada, Togoro

Laboratory of Soil Fertility and Plant Nutrition, Faculty of Agriculture, Kyushu University

https://doi.org/10.5109/22818

出版情報：九州大学大学院農学研究院紀要. 17 (1)，pp.49-65，1972-08. Kyushu University バージョン：

権利関係 : 


\title{
Effect of Nitrogenous Forms on Immobilization and Release of Nitrogen in Soil
}

\author{
Ziauddin Ahmad*, Hideaki Kai and Togoro Harada \\ Laboratory of Soil Fertility and Plant Nutrition, Faculty of Agriculture, \\ Kyushu University, Fukuoka
}

(Received December 5, 1971)

\begin{abstract}
The effect of nitrogenous forms on immobilization and release of nitrogen following addition of glucose and mineral nitrogen to soils was studied. The amount of nitrogen immobilized increased with increasing $\mathrm{C} / \mathrm{N}$ ratio independent of the forms of nitrogen added, but the nitrogen immobilized to a maximum at a given $\mathrm{C} / \mathrm{N}$ ratio was a little larger in the form of ammonia than in the form of nitrate. The amount of carbon which must be added to the soil in order to immobilize one unit of nitrogen into organic form was larger in the latter than in the former. The percentage of released nitrogen to the maximum-immobilized nitrogen at a given $\mathrm{C} / \mathrm{N}$ ratio was higher in the latter than in the former.
\end{abstract}

Several investigators (Allison 1927, Jansson 1955, Winsor et al. 1956, Allison et al. 1962, Harada et al. 1968, Kai et al. 1969, Ahmad et al. 1969) have reported that incorporation of energy rich materials together with mineral nitrogen to soil causes immediate nitrogen immobilization and after some time turns into an increased mineralization. It has been observed that the immobilization and mineralization processes in soil are governed by many factors among which the kind of carbonaceous materials incorporated, their $\mathrm{C} / \mathrm{N}$ ratio, form of nitrogen added, soil reaction, soil temperature, soil moisture, etc. play an important role.

According to some authors (Richards et al. 1935, Jansson 1955, Winsor et al. 1956, Jansson 1958, Allison et al. 1962, Broadbent et al. 1962), the microorganisms concerned in the immobilization of nitrogen showed a marked preference for the form of ammonia rather to the form of nitrate, but this view was contradicted by others (Walunjkar, Bartholomew and Woltz, 1959), and Norman (1931) pointed out that ammonium and nitrate nitrogen were equally available to the microorganisms as a source of nitrogen. The variation in the findings of workers may possibly be due to their experimental plans and procedures and often give different nitrogen immobilization values.

With a view to add more exact informations and to contribute to a better understanding of the processes of immobilization and release of nitrogen in soil, the present experiment was designed to observe the role played by the different nitrogenous forms in the processes following addition of glucose and mineral nitrogen to soil.

* Present address: Department of Soil Science, University of Dacca, Dacca-2, Bangladesh. 


\section{MATERIALS AND METHODS}

\section{Soil samples}

Soil samples used in this study were collected from the ploughed layers of four soils, two of which have been receiving the three elements of fertilizer and compost and the other two receiving no fertilizer and compost since about last forty years. They are located at the lowland and highland fields of the Kyushu University farm. The moist soils were sieved through a $2 \mathrm{~mm}$ sieve. The denotation and some of the chemical and physical properties of the soil samples are given in Table 1.

Table 1. Description of soils used.

\begin{tabular}{c|c|c|c|c|c}
\hline Soils & Denotation & Texture & $\begin{array}{c}\text { Total C } \\
(\%)\end{array}$ & $\begin{array}{c}\text { Total N } \\
(\%)\end{array}$ & $\begin{array}{c}\text { pH } \\
(\mathrm{KC} 1)\end{array}$ \\
\hline Lowland, fertilized & $\mathrm{LF}$ & $\mathrm{LiC}$ & 2.65 & 0.23 & 4.70 \\
not fertilized & $\mathrm{LnoF}$ & $\mathrm{LiC}$ & 1.86 & 0.15 & 4.50 \\
Highland, fertilized & $\mathrm{HF}$ & $\mathrm{CL}$ & 1.38 & 0.11 & 5.15 \\
not fertilized & HnoF & $\mathrm{CL}$ & 0.89 & 0.05 & 4.19 \\
\hline
\end{tabular}

\section{Incubation and determination}

Moist soil samples corresponding to $20 \mathrm{~g}$ dry soil were weighed into $50 \mathrm{ml}$ Erlenmeyer flasks, and treated with $4 \mathrm{mg} \mathrm{N}$ as $\left(\mathrm{NH}_{4}\right)_{2} \mathrm{SO}_{4}$ or $\mathrm{NaNO}_{3}$ and various levels of $\mathrm{C}$ as glucose. The level of mineral nitrogen added was constant throughout the experiments, only carbon level was varied to give different $\mathrm{C} / \mathrm{N}$ ratios. Carbon added to $20 \mathrm{~g}$ dry soil as glucose was $0,8,16,32$ and $64 \mathrm{mg}$ giving $\mathrm{C} / \mathrm{N}$ ratio $0,2,4,8$ and 16 in all the soils. An adequate amount of $\mathrm{CaCO}_{3}$ was added to bring the $\mathrm{pH}$ of the soils to 6.2 , and then the soil water content was adjusted to 60 per cent of maximum water holding capacity with additional water. The basal dressing with $2 \mathrm{mg} \mathrm{P}_{2} \mathrm{O}_{5}, 2 \mathrm{mg} \mathrm{K}_{2} \mathrm{O}$ and $0.5 \mathrm{mg} \mathrm{MgO}$ per $20 \mathrm{~g}$ dry soil was also made. All the flasks were covered with polyethylene film and incubated at $30^{\circ} \mathrm{C}$ for the periods of 3 days and $1,2,4,8$ and 12 weeks, respectively, water being added at intervals to compensate for water loss during incubation as determined by weighing the flasks. Mineral nitrogen produced during various time intervals of incubation was extracted with $\mathrm{N} \mathrm{KC1} \mathrm{(pH} \mathrm{7.0)} \mathrm{and} \mathrm{determined} \mathrm{by}$ Conway's microdiffusion method (Bremner et al. 1955, Kai 1961). Determination of mineral nitrogen was made on duplicate flasks of soil. The amount of nitrogen immobilized at a given $\mathrm{C} / \mathrm{N}$ ratio has been calculated as the difference in content of mineral nitrogen between the soil treated with mineral nitrogen and the soil treated with mineral nitrogen and glucose. The amount of nitrogen released has been calculated as the difference in content of mineral nitrogen between the soil at a time of maximum immobilization of nitrogen and the soil at a given time interval. The term "check soil" refers to soil receiving no treatment other than the maintenance of moisture content.

\section{RESULTS AND DISCUSSION}

The results obtained by the experiments on the transformation of nitrogen 
Table 2. Transformation of mineral nitrogen at various time intervals, following addition of either glucose and $\left(\mathrm{NH}_{4}\right)_{2} \mathrm{SO}_{4}$ or glucose and $\mathrm{NaNO}_{3}$ to $\mathrm{LF}$ soil.

(mg N/100g dry soil)

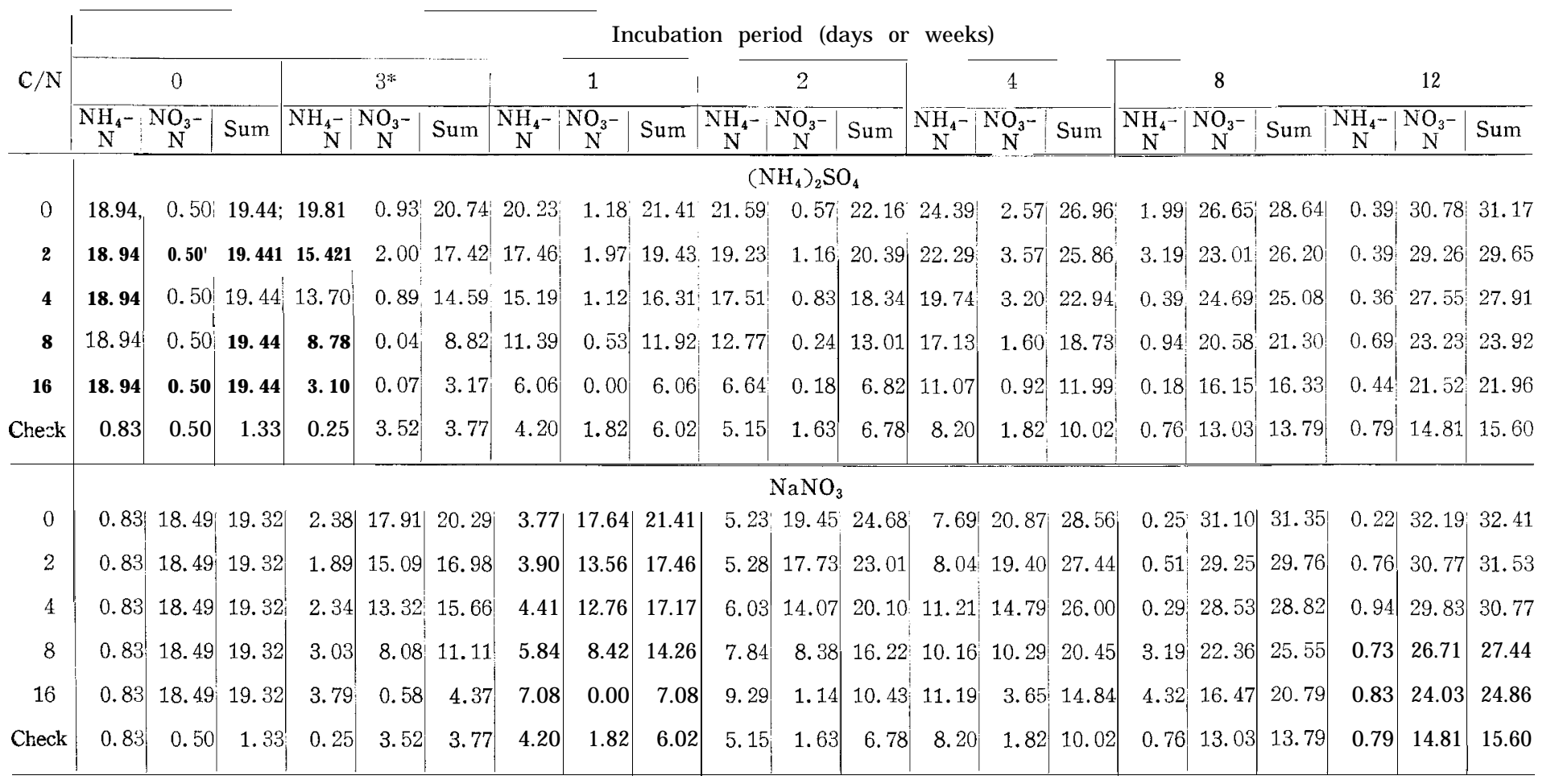

* Days. 
following addition of glucose and mineral nitrogen as $\left(\mathrm{NH}_{4}\right)_{2} \mathrm{SO}_{4}$ or $\mathrm{NaNO}_{3}$ to LF-, LnoF-, HF- and HnoF-soils are shown in Tables 2, 6, 10 and 14, respectively.
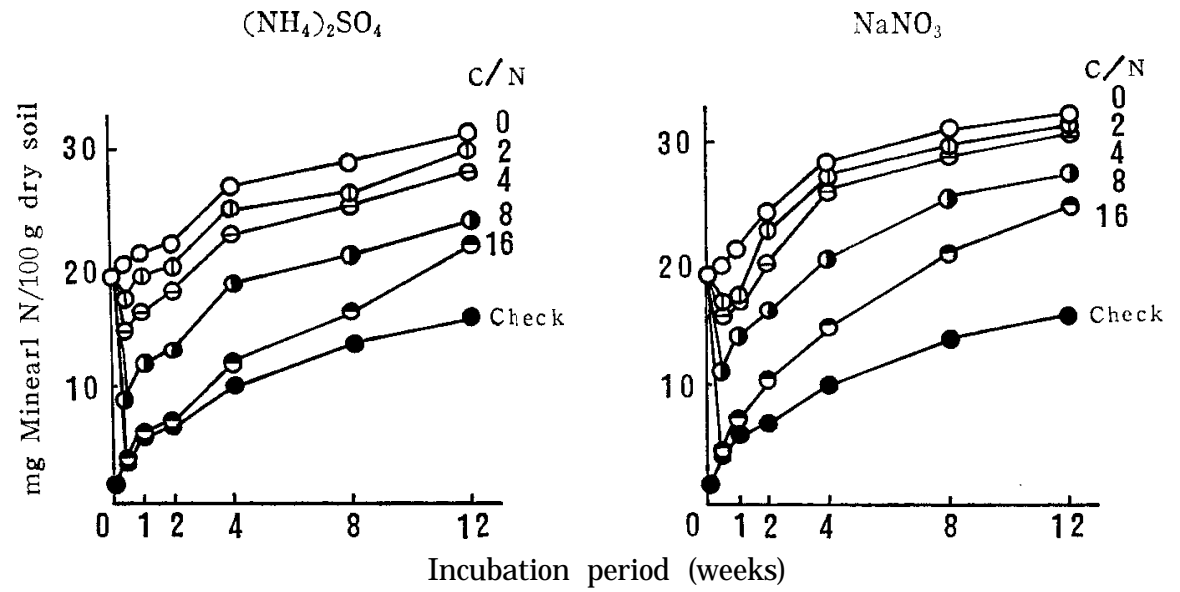

Fig. 1. Amounts of mineral nitrogen at various time intervals, following addition of either glucose and $\left(\mathrm{NH}_{4}\right)_{2} \mathrm{SO}_{4}$ or glucose and $\mathrm{NaNO}_{3}$ to $\mathrm{LF}$ soil.

In LF soil, as shown in Table 2 and Fig. 1, it was clear that immobilization proceeded rapidly, reached its maximum on 3-day incubation and was followed by a release of nitrogen irrespective of the $\mathrm{C} / \mathrm{N}$ ratios and the forms of nitrogen. These trends were similar to the results obtained by Allison et al. (1960) and Harada et al. (1968). The amounts of immobilized nitrogen, as shown in Table 3 , varied with the varing $\mathrm{C} / \mathrm{N}$ ratio. The wider the $\mathrm{C} / \mathrm{N}$ ratio, the larger the amount of immobilized nitrogen in both the forms of nitrogen, and the estimated amount of immobilized nitrogen was found larger in the form of ammonia given as $\left(\mathrm{NH}_{4}\right)_{2} \mathrm{SO}_{4}$ than in the form of nitrate given as $\mathrm{NaNO}_{3}$, which agreed with

Table 3. Estimated amounts of immobilized nitrogen at various time intervals, following addition of either glucose and $\left(\mathrm{NH}_{4}\right)_{2} \mathrm{SO}_{4}$ or glucose and $\mathrm{NaNO}_{3}$ to $\mathrm{LF}$ soil.

(mg $\mathrm{N} / 100 \mathrm{~g}$ dry soil)

\begin{tabular}{|c|c|c|c|c|c|c|c|}
\hline \multirow{2}{*}{$\mathrm{C} / \mathrm{N}$} & \multicolumn{7}{|c|}{ Incubation period (days or weeks) } \\
\hline & $3^{*}$ & 1 & 2 & 4 & 8 & & 12 \\
\hline \multirow{4}{*}{$\begin{array}{r}2 \\
4 \\
8 \\
16\end{array}$} & \multicolumn{7}{|c|}{$\left(\mathrm{NH}_{4}\right)_{2} \mathrm{SO}_{4}$} \\
\hline & 3.326 .15 & 1.985 .10 & 1.773 .82 & $4.021,10$ & 2.443 .56 & 1 & 1.523 .26 \\
\hline & 11.9217 .57 & 15.359 .49 & 15.349 .15 & 14.978 .23 & 12.317 .34 & 1 & 7.259 .21 \\
\hline & \multicolumn{7}{|c|}{$\mathrm{NaNO}_{3}$} \\
\hline $\begin{array}{r}2 \\
4 \\
8 \\
16\end{array}$ & $\begin{array}{r}3.31 \\
4.63 \\
9.18 \\
15.92\end{array}$ & $\begin{array}{r}3.95 \\
4.24 \\
7.15 \\
14.33\end{array}$ & $\begin{array}{r}1.67 \\
4.58 \\
8.46 \\
14.25\end{array}$ & $\begin{array}{r}1.12 \\
2.56 \\
8.11 \\
13.72\end{array}$ & $\begin{array}{r}1.59 \\
2.53 \\
5.80 \\
10.56\end{array}$ & $\begin{array}{l}1 \\
1\end{array}$ & $\begin{array}{l}0.88 \\
1.64 \\
4.97 \\
7.55\end{array}$ \\
\hline
\end{tabular}

* Days. 
the findings of Richards and Shrikhande (1935), Winsor and Pollard (1956), Jansson (1958) and Broadbent and Tyler (1962), but was contrary to the finding of Walunjkar et al. (1959). The rate of release of nitrogen was found faster at an early period than at a late period in both the forms of nitrogen as shown in Tables 4 and 5 .

Table 4. Estimated amounts of released nitrogen at various time intervals, following addition of either glucose and $\left(\mathrm{NH}_{4}\right)_{2} \mathrm{SO}_{4}$ or glucose and $\mathrm{NaNO}_{3}$ to $\mathrm{LF}$ soil.

(mg N/100 g dry soil)

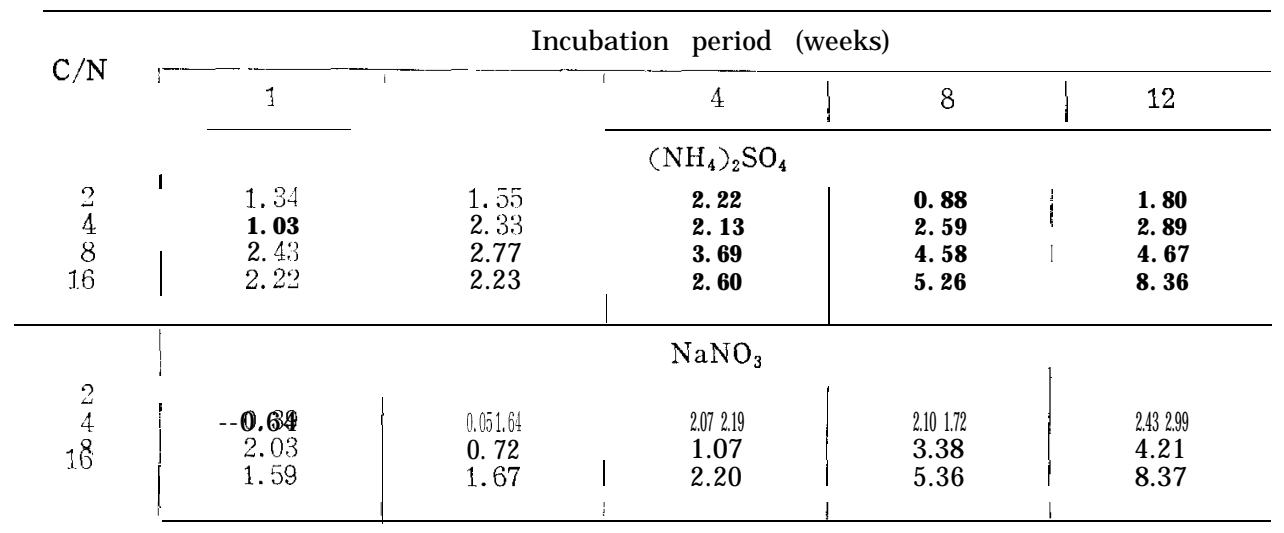

Table 5. Estimated rate of release of immobilized nitrogen per half a week at various time intervals, following addition of either glucose and $\left(\mathrm{NH}_{4}\right)_{2} \mathrm{SO}_{4}$ or glucose and $\mathrm{NaNO}_{3}$ to $\mathrm{LF}$ soil.

(mg N/100g dry soil/half week)

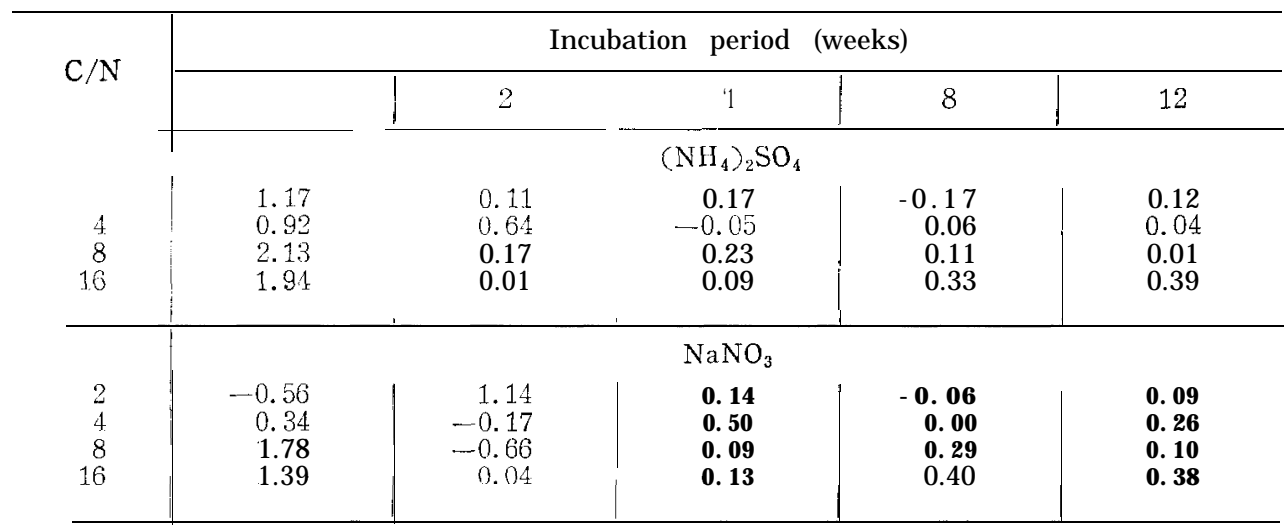

In LnoF soil, as shown in Table 6 and Fig. 2, the trend of immobilization and release of nitrogen which was found in LnoF soil was the same in nature that was found in LF soil. Here also we found that immobilization reached its maximum on 3-day incubation and was followed by a release of nitrogen. And as shown in Table 7 , the wider the $\mathrm{C} / \mathrm{N}$ ratio, the larger the amount of immobilized nitrogen. Here also, the superiority of $\left(\mathrm{NH}_{4}\right)_{2} \mathrm{SO}_{4}$ to $\mathrm{NaNO}_{3}$ on the immobilization of nitrogen was maintained. The rate of release of nitrogen was 


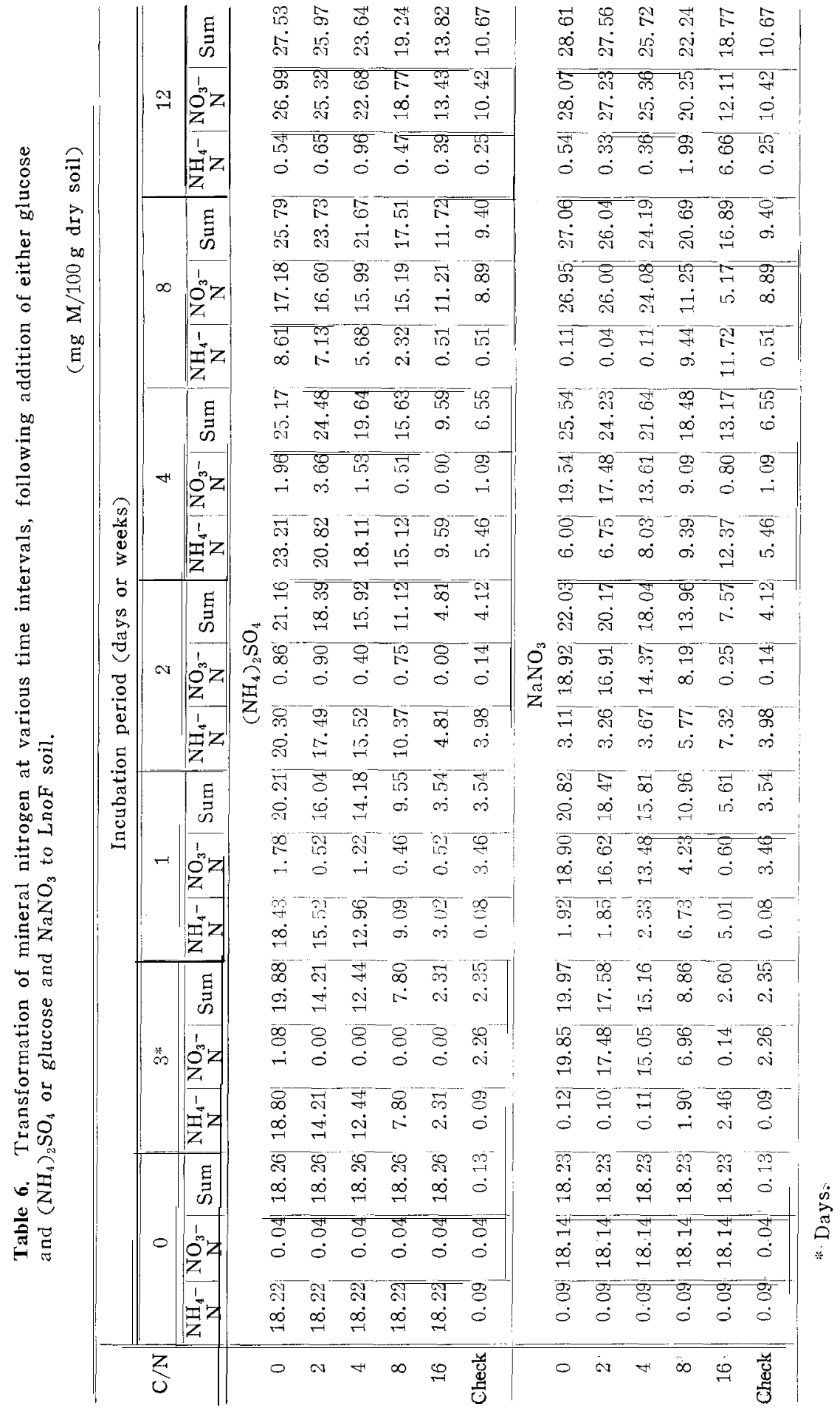




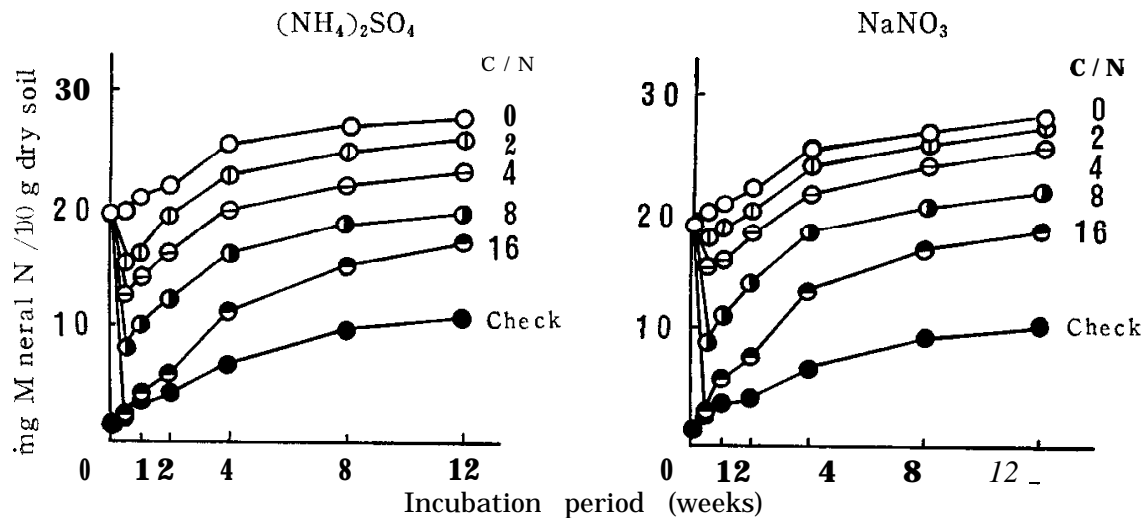

Fig. 2. Amounts of mineral nitrogen at various time intervals, following addition of either glucose and $\left(\mathrm{NH}_{4}\right)_{2} \mathrm{SO}_{4}$ or glucose and $\mathrm{NaNO}_{3}$ to $\mathrm{LnoF}$ soil.

Table 7. Estimated amounts of immobilized nitrogen at various time intervals, following addition of either glucose and $\left(\mathrm{NH}_{4}\right)_{2} \mathrm{SO}_{4}$ or glucose and $\mathrm{NaNO}_{3}$ to $\mathrm{LnoF}$ soil.

(mg N/100 g dry soil)

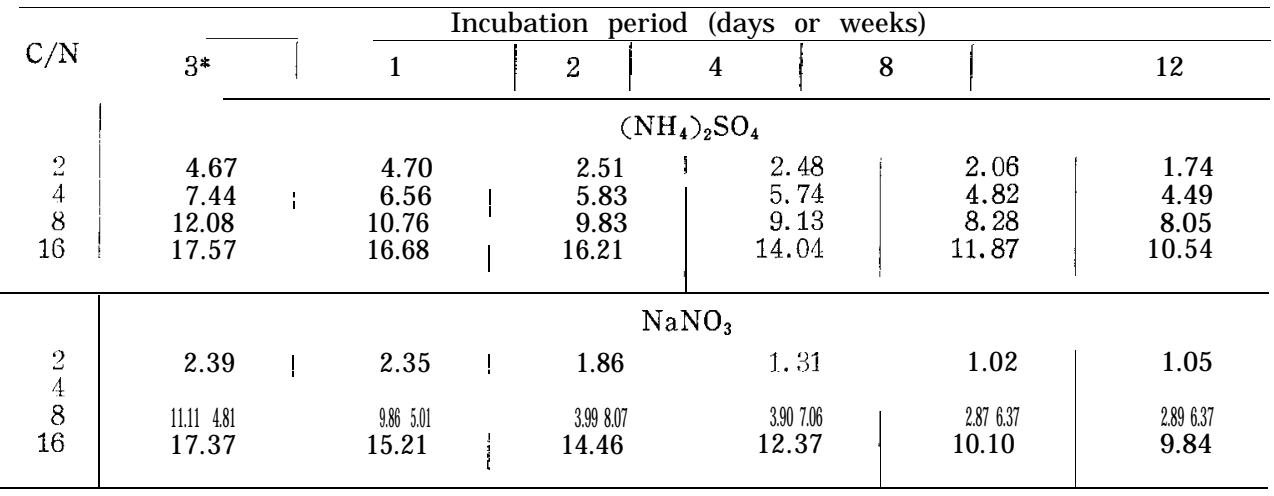

* Days.

Table 8. Estimated amounts of released nitrogen at various time intervals, following addition of either glucose and $\left(\mathrm{NH}_{4}\right)_{2} \mathrm{SO}_{4}$ or glucose and $\mathrm{NaNO}_{3}$ to LnoF soil.

(mg N/100 g dry soil)

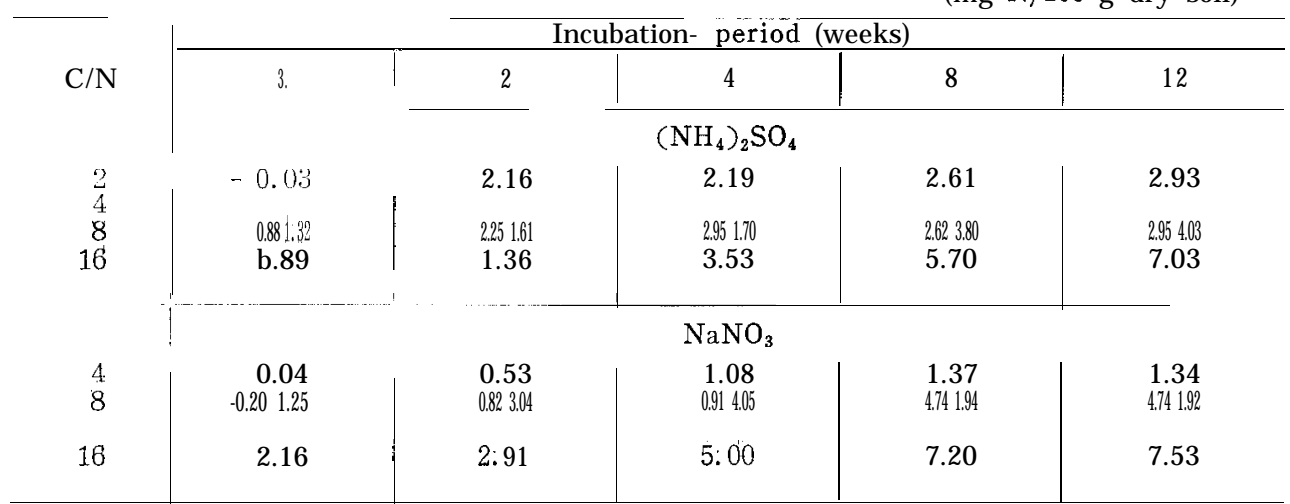


Table 9. Estimated rate of release of immobilized nitrogen per half a week at various time intervals, following addition of either glucose and $\left(\mathrm{NH}_{4}\right)_{2} \mathrm{SO}_{4}$ or glucose and $\mathrm{NaNO}_{3}$ to LnoF soil.

(mg N/100 g dry soil/half week)

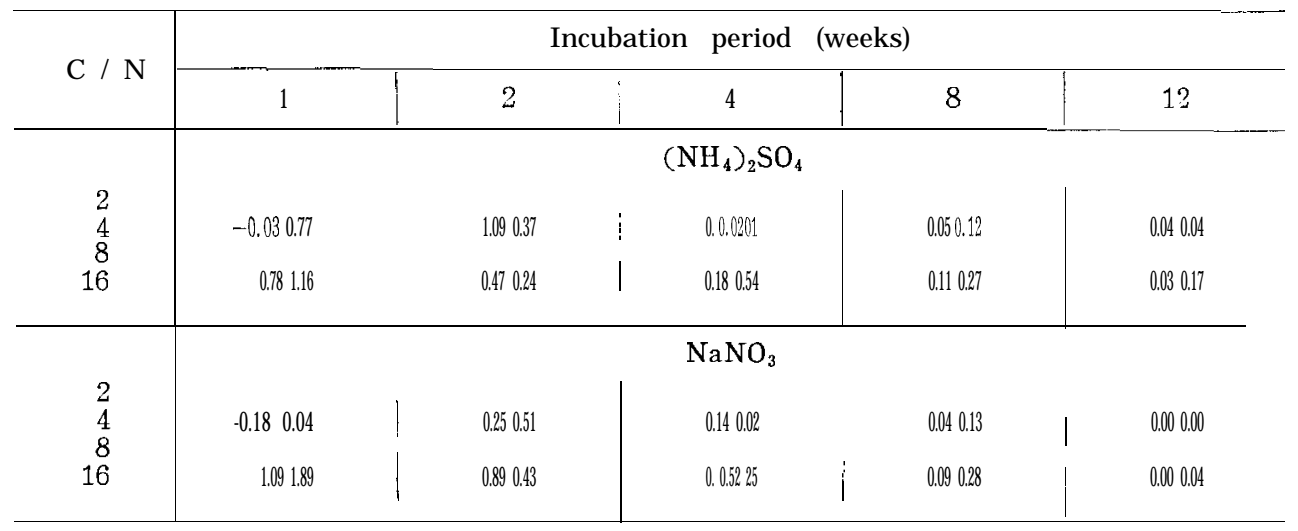

also faster at an early period than at a late period in both the forms of nitrogen, as given in Tables 8 and 9 .

In HF soil, as shown in Table 10 and Fig. 3, it was also observed that immobilization occurred just after addition of mineral nitrogen together with glucose and reached its maximum on 3-day incubation irrespective of the $\mathrm{C} / \mathrm{N}$ ratio and the forms of nitrogen added. And as shown in Table 11, the wider the $\mathrm{C} / \mathrm{N}$ ratio, the larger the amount of immobilized nitrogen. The nature of immobilization and release of nitrogen in $\mathrm{HF}$ soil was also the same that in LF and LnoF soils. Only the amounts of immobilized and released nitrogen in $\mathrm{HF}$ soil were found smaller than those in $\mathrm{LF}$ and $\mathrm{LnoF}$ soils. Here also, $\left(\mathrm{NH}_{4}\right)_{2} \mathrm{SO}_{4}$ and $\mathrm{NaNO}_{3}$ maintained their respective position with regard to immobilization and release of nitrogen in the soil. And the rate of release of nitrogen in both the forms of nitrogen was also the same nature as found in LF and LnoF soils, as shown in Tables 12 and 13 .

From Table 14 and Fig. 4 in which the results obtained from HnoF soil are shown, it was seen that immobilization and release of nitrogen in HnoF soil which was smallest in total nitrogen among the four soils used, were also the same manner as found in LF, LnoF and HF soils. Here also, maximum immobilization occurred on 3-day incubation, and was followed by a release of nitrogen. Here also, as shown in Table 15 , the wider the $\mathrm{C} / \mathrm{N}$ ratio, the larger the amount of immobilized nitrogen, and $\left(\mathrm{NH}_{4}\right)_{2} \mathrm{SO}_{4}$ was found superior on immobilization to $\mathrm{NaNO}_{3}$. The rate of release of nitrogen was also faster at an early period of incubation than at a late period in both the forms of nitrogen, as shown in Tables 16 and 17.

In view of the results obtained on immobilization and release of nitrogen following addition of glucose and mineral nitrogen as $\left(\mathrm{NH}_{4}\right)_{2} \mathrm{SO}_{4}$ or $\mathrm{NaNO}_{3}$ to soil, it can be clearly said that the nature of immobilization and release of nitrogen was the same in all the soils used.

Experimental results obtained under the experimental conditions employed 
Table 10. Transformation of mineral nitrogen at various time intervals, following addition of either glucose and $\left(\mathrm{NH}_{4}\right)_{2} \mathrm{SO}_{4}$ or glucose and $\mathrm{NaNO}_{3}$ to $\mathrm{HF}$ soil.

$(\mathrm{mg} \mathrm{N} / 100 \mathrm{~g}$ dry soil

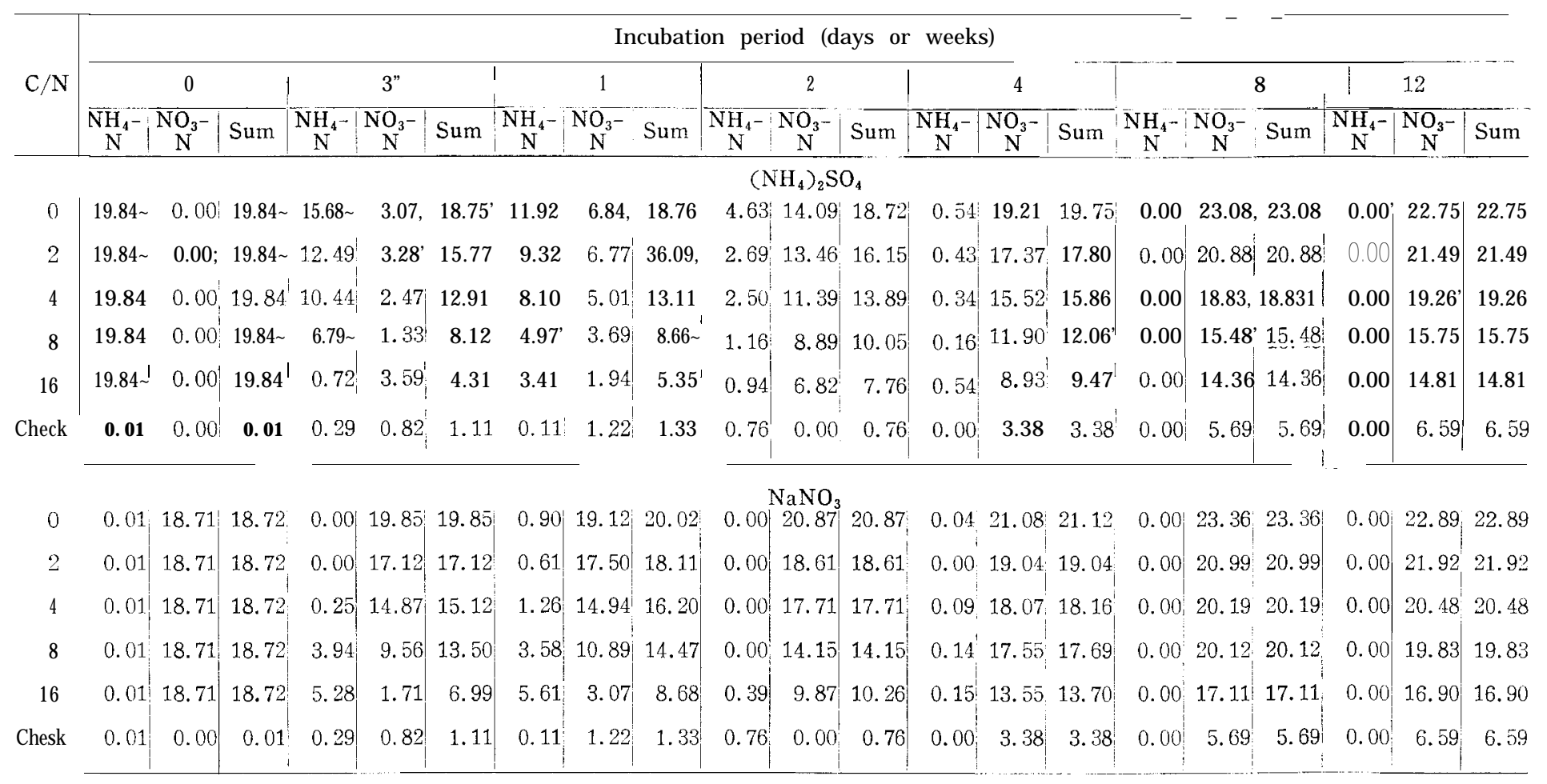

* Days. 


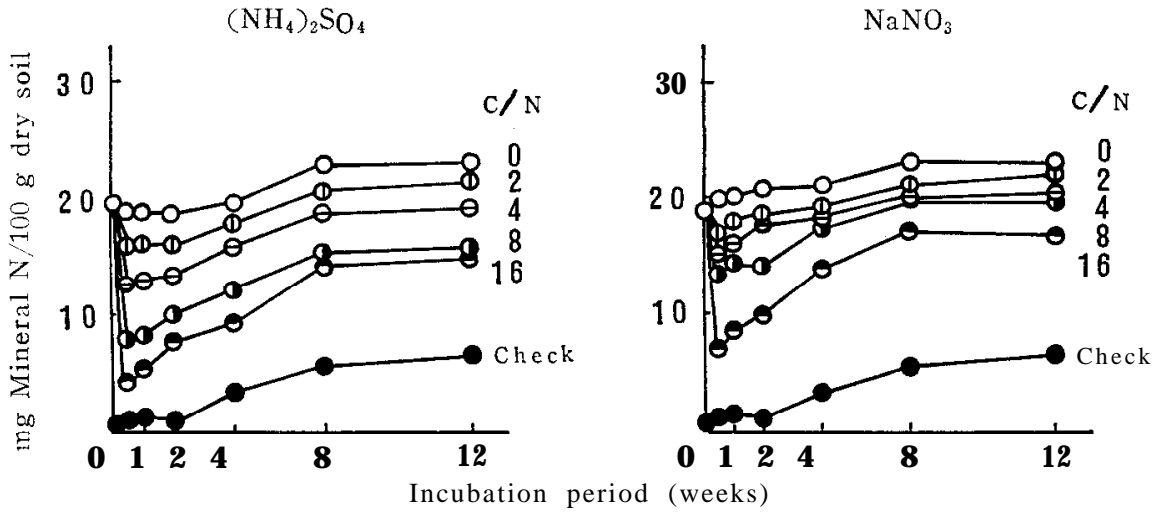

Fig. 3. Amounts of mineral nitrogen at various time intervals, following addition of either glucose and $\left(\mathrm{NH}_{4}\right)_{2} \mathrm{SO}_{4}$ or glucose and $\mathrm{NaNO}_{3}$ to $\mathrm{HF}$ soil.

Table 11. Estimated amounts of immobilized nitrogen at various time intervals, following addition of either glucose and $\left(\mathrm{NH}_{4}\right)_{2} \mathrm{SO}_{4}$ or glucose and $\mathrm{NaNO}_{3}$ to HF soil.

( $\mathrm{mg} \mathrm{N} / 100 \mathrm{~g}$ dry soil)

\begin{tabular}{|c|c|c|c|c|c|c|c|c|}
\hline \multirow[b]{2}{*}{$\mathrm{C} / \mathrm{N}$} & \multicolumn{8}{|c|}{ Incubation period (days or weeks) } \\
\hline & I $--3^{*}:--$ & & 1 & 2 & 4 & i & 8 & 12 \\
\hline \multirow{6}{*}{$\begin{array}{r}3 \\
4 \\
8 \\
16\end{array}$} & \multicolumn{8}{|c|}{$\left(\mathrm{NH}_{4}\right)_{2} \mathrm{SO}_{4}$} \\
\hline & 2.98 & 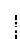 & 2.67 & 2.57 & 1.95 & 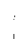 & 2.20 & 1.26 \\
\hline & 5.84 & & 565 & 4.83 & 3.89 & & 4.25 & 3.49 \\
\hline & & & $0+0$ & 8.67 & 7.69 & & 7.60 & 7.00 \\
\hline & 14.443 & I & 13.41 & 10.96 & 10.28 & & 8.72 & 7.94 \\
\hline & \multicolumn{8}{|c|}{$\mathrm{NaNO}_{3}$} \\
\hline$\ddot{4}$ & $27 \div: 4.73$ & & 3.821 .91 & 3.16226 & 296208 & : & 3.17237 & 0972.41 \\
\hline 8 & 6. 35 & & 5.55 & 5.72 & 3.43 & t & 3.24 & 3.06 \\
\hline 16 & 12.86 & 1 & 11.34 & 10.61 & 7.42 & & 6.25 & 5.99 \\
\hline
\end{tabular}

* Days.

Table 12. Estimated amounts of released nitrogen at various time intervals, following addition of either glucose and $\left(\mathrm{NH}_{4}\right)_{2} \mathrm{SO}_{4}$ or glucose and $\mathrm{NaNO}_{3}$ to $\mathrm{HF}$ soil.

(mg N/100g dry soil)

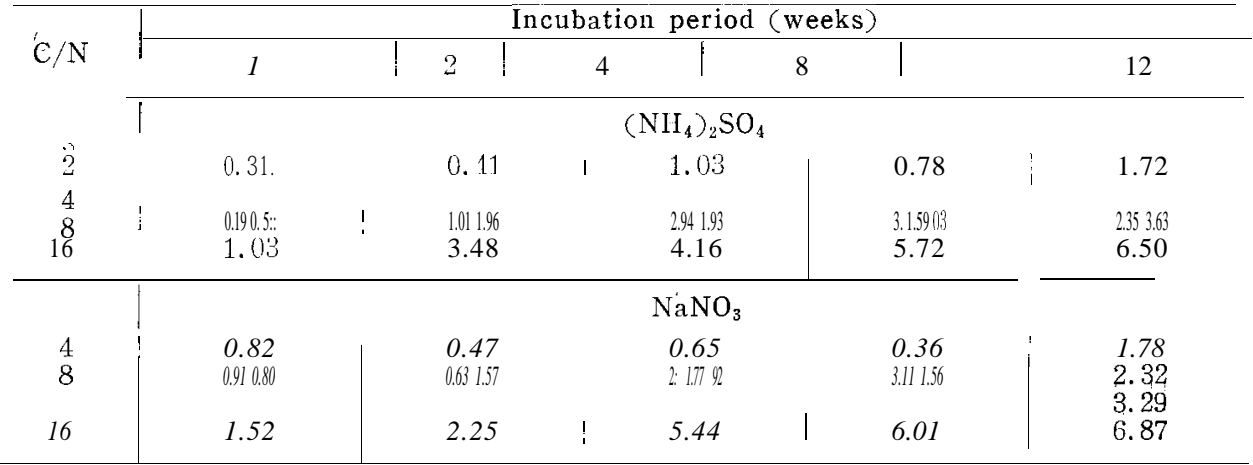


Table 13. Estimated rate of release of immobilized nitrogen per half a week at various time intervals, following addition of either glucose and $\left(\mathrm{NH}_{4}\right)_{2} \mathrm{SO}_{4}$ or glucose and $\mathrm{NaNO}_{3}$ to $\mathrm{HF}$ soil.

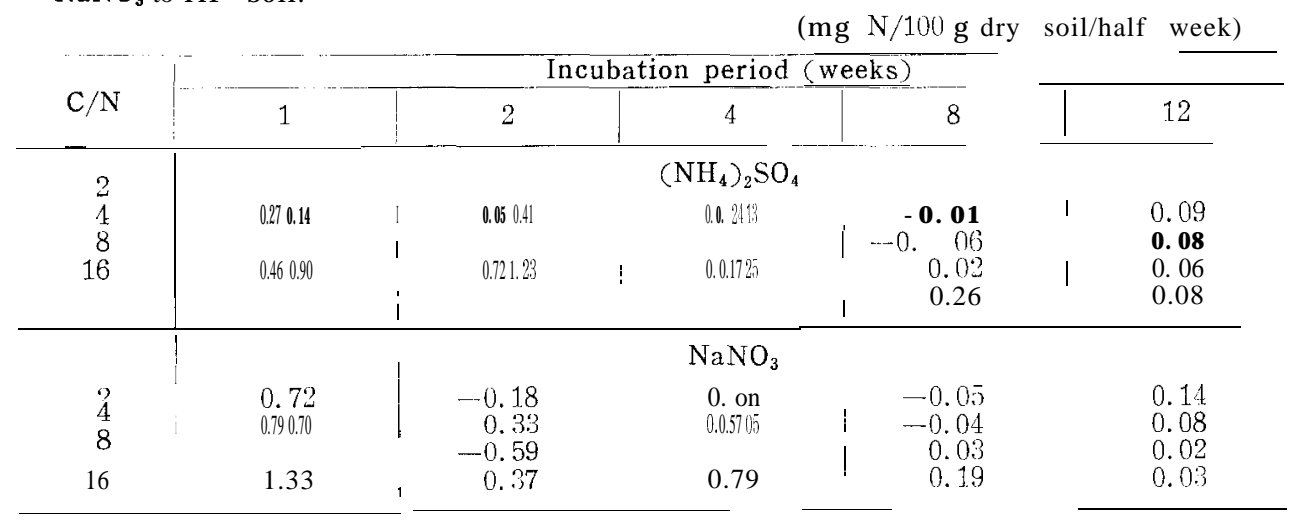

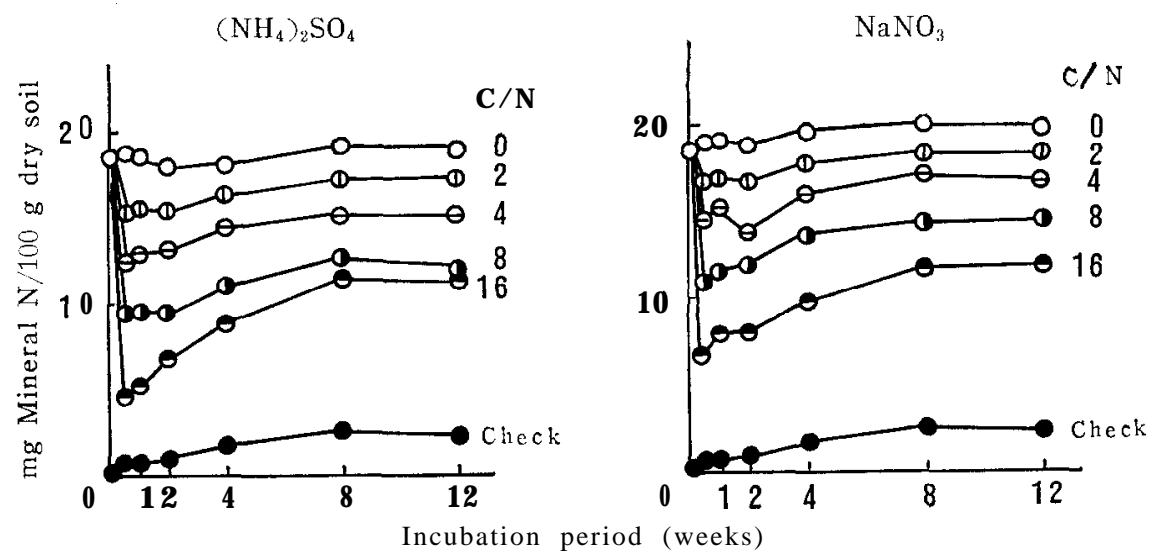

Fig. 4. Amounts of mineral nitrogen at various time intervals, following addition of either giucoseand $\left(\mathrm{NH}_{4}\right)_{2} \mathrm{SO}_{4}$ or glucose and $\mathrm{NaNO}_{3}$ to $\mathrm{HnoF}$ soil.

Table 15. Estimated amounts of immobilized nitrogen at various time intervals, following addition of either glucose and $\left(\mathrm{NH}_{4}\right)_{2} \mathrm{SO}_{4}$ or glucose and $\mathrm{NaNO}_{3}$ to HnoF soil.

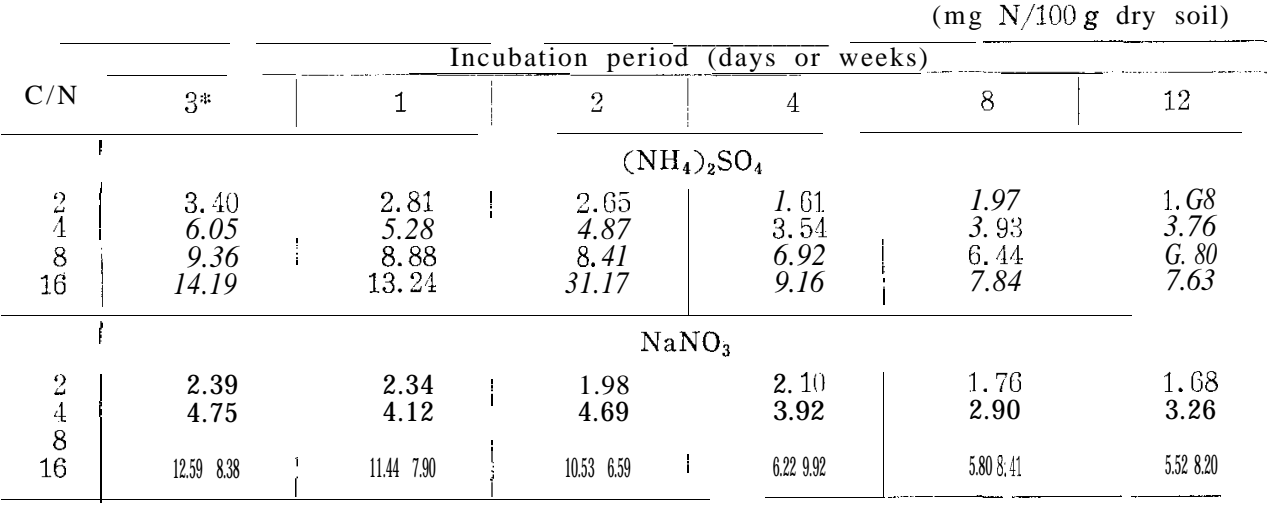

\footnotetext{
* Days.
} 
Table 14. Transformation of mineral nitrogen at various time intervals, following addition of either glucose and $\left(\mathrm{NH}_{4}\right)_{2} \mathrm{SO}_{4}$ or glucose and $\mathrm{NaNO}_{3}$ to $\mathrm{HnoF}$ soil.

(mg N/100g dry soil)

\begin{tabular}{|c|c|c|c|c|c|c|c|c|c|c|c|c|c|c|c|c|c|c|c|c|c|}
\hline \multirow{3}{*}{$\mathrm{C} / \mathrm{N}$} & \multicolumn{21}{|c|}{ Incubation period (days or weeks) } \\
\hline & \multicolumn{3}{|c|}{0} & \multicolumn{3}{|c|}{$3^{*}$} & \multicolumn{3}{|c|}{1} & \multicolumn{3}{|c|}{2} & \multicolumn{3}{|c|}{4} & \multicolumn{3}{|c|}{8} & \multicolumn{3}{|c|}{12} \\
\hline & $\begin{array}{c}\mathrm{NH}_{4}- \\
\mathrm{N}\end{array}$ & $\begin{array}{c}\mathrm{NO}_{3}- \\
\mathrm{N}\end{array}$ & Sum & $\begin{array}{c}\mathrm{NH}_{4}-1 \\
\mathrm{~N}\end{array}$ & $\begin{array}{c}\mathrm{NO}_{3}- \\
\mathrm{N}\end{array}$ & Sum & \begin{tabular}{|c|}
$\mathrm{NH}_{4}-1$ \\
$\mathrm{~N}$
\end{tabular} & $\begin{array}{c}\mathrm{NO}_{3}- \\
\mathrm{N} \\
\end{array}$ & Sum & $\begin{array}{c}\mathrm{NH}_{4}- \\
\mathrm{N}\end{array}$ & \begin{tabular}{|c|}
$\mathrm{NO}_{3-}$ \\
$\mathrm{N}$ \\
\end{tabular} & Sum & $\begin{array}{c}\mathrm{NH}_{4^{-}} \\
\mathrm{N}\end{array}$ & $\begin{array}{c}\mathrm{NO}_{3}- \\
\mathrm{N}\end{array}$ & Sum & $\begin{array}{c}\mathrm{NH}_{4^{-}} \\
\mathbf{N}\end{array}$ & $\begin{array}{c}\mathrm{NO}_{3}- \\
\mathrm{N}\end{array}$ & Sum & $\begin{array}{c}\mathrm{NH}_{4} \\
\mathrm{~N}\end{array}$ & $\begin{array}{c}\mathrm{NO}_{3-} \\
\mathrm{N}\end{array}$ & Sum \\
\hline & \multicolumn{21}{|c|}{$\left(\mathrm{NH}_{4}\right)_{2} \mathrm{SO}_{4}$} \\
\hline 0 & 18.54 & 0.00 & 18.54 & 18.01 & 0.77 & 18.78 & 17.15 & 1.36 & 1.8 .51 & 13.23 & 4.67 & 17.90 & 3.13 & 14.90 & 18.03 & 0.00 & 19.15 & 19.15 & 0.00 & 18.69 & 18.69 \\
\hline 2 & 18.54 & 0.00 & 18.54 & 15.25 & 0.13 & 15.38 & 1.1 .18 & 0.52 & 15.70 & 13.71 & 1.54 & 15.25 & 10.28 & 6.14 & 16.42 & 0.00 & 17.18 & 17.18 & 0.00 & 17.01 & 17.01 \\
\hline 4 & 18.54 & 0.00 & 18.54 & 12.73 & 0.00 & 12.73 & 13.07 & 0.16 & 13.23 & 11.03 & 2.00 & 13.03 & 5.09 & 9.40 & 14.49 & 0.00 & 15.22 & 15.22 & 0.00 & 14.93 & 14.93 \\
\hline 8 & 18.54 & 0.00 & 18.54 & 8.77 & 0.65 & 9.42 & 8.86 & 0.77 & 9.63 & 8.08 & 1.41 & $9.49^{\prime}$ & 5.30 & 5.81. & 11.11 & 0.00 & 12.71 & 12.71 & 0.00 & 11.89 & 11.89 \\
\hline 16 & 18.54 & 0.00 & 18.54 & 4.17 & 0.42 & 4.59 & 4.94 & 0.33 & 5.27 & 5.96 & 0.77 & 6.73 & 2.29 & 6.58 & 8.87 & 0.00 & 11.31 & 11.31 & 0.00 & 11.06 & 11.06 \\
\hline Check & 0.02 & 0.00 & 0.02 & 0.00 & 0.47 & 0.47 & 0.00 & 0.32 & 0.32 & 0.00 & 0.72 & 0.72 & 0.07 & 1.72 & 1.79 & 0.00 & 2.51 & 2.51 & 0.00 & 2.15 & 2.15 \\
\hline 0 & \multicolumn{21}{|c|}{$\mathrm{NaNO}_{3}$} \\
\hline 2 & 0.02 & 18.43 & 18.45 & 0.32 & 16.57 & 16.89 & 0.93 & 16.10 & 17.03 & 0.25 & 16.28 & 16.53 & 0.14 & 17.47 & 17.61 & 0.00 & 18.29 & 18.29 & 0.00 & 18.19 & 18.19 \\
\hline 4 & 0.02 & 18.43 & 18.45 & 0.35 & 14.17 & 14.52 & 1.59 & 13.66 & 15.25 & 0.00 & $\begin{array}{l}13.82 \\
\end{array}$ & 13.82 & 0.21 & 15.58 & 15.79 & 0.00 & 17.15 & 17.15 & 0.00 & 16.61 & 16.61 \\
\hline 8 & 0.02 & 18.43 & 18.45 & 1.68 & 9.22 & 10.90 & 2.92 & 8.55 & 11.47 & 1.55 & 10.37 & 11.92 & 0.13 & 13.06 & 13.49 & 0.00 & 14.25 & 14.25 & 0.00 & 14.35 & 14.35 \\
\hline 16 & 0.02 & 18.43 & 18.45 & 4.01 & 2.68 & 6.69 & 4.29 & 3.64 & 7.93 & 2.83 & 5.15 & 7.98 & 0.35 & 9.44 & 9.79 & 0.00 & 11.64 & 11.64 & 0.00 & 11.67 & 11.67 \\
\hline Check & 0.02 & 0.00 & 0.02 & 0.00 & 0.47 & 0.47 & 0.00 & 0.32 & 0.32 & 0.00 & 0.72 & 0.72 & 0.07 & 1.72 & 1.79 & 0.00 & 2.51 & 2.51 & 0.00 & 2.15 & 2.15 \\
\hline
\end{tabular}

* Days. 
Table 16. Estimated amounts of released nitrogen at various time intervals, following addition of either glucose and $\left(\mathrm{NH}_{4}\right)_{2} \mathrm{SO}_{4}$ or glucose and $\mathrm{NaNO}_{3}$ to $\mathrm{HnoF}$ soil.

( $\mathrm{mg} \mathrm{N} / 100$ g dry soil)

\begin{tabular}{|c|c|c|c|c|c|c|}
\hline \multirow{2}{*}{$\mathrm{C} / \mathrm{N}$} & \multicolumn{6}{|c|}{ Incubation period (weeks) } \\
\hline & 1 & 2 & 4 & 8 & I & 12 \\
\hline $\begin{array}{r}2 \\
8 \\
16\end{array}$ & $\begin{array}{l}0.59 \\
0.77 \\
0.48 \\
0.95\end{array}$ & $\begin{array}{l}0.75 \\
\text { I. } 18 \\
0.95 \\
3.02\end{array}$ & $\begin{array}{r}\left.\mathrm{r}_{4}\right)_{2} \\
1.79 \\
2.51 \\
2.44 \\
5.0\end{array}$ & $\begin{array}{l}1.43 \\
2: 12 \\
2.92 \\
6.35\end{array}$ & 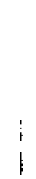 & $\begin{array}{l}1.72 \\
2.29 \\
2.56 \\
6.56\end{array}$ \\
\hline $\begin{array}{r}2 \\
4 \\
8 \\
16\end{array}$ & $\begin{array}{l}0.05 \\
0.63 \\
0.48 \\
1.15\end{array}$ & $\begin{array}{l}0.41 \\
0.06 \\
1.79 \\
2.06\end{array}$ & $\begin{array}{c}\mathrm{NaN} \\
0.29 \\
0.83 \\
2.16 \\
2.67\end{array}$ & $\begin{array}{l}0.63 \\
1.85 \\
2.58 \\
4.18\end{array}$ & & $\begin{array}{l}0.71 \\
1.49 \\
2.86 \\
4.39\end{array}$ \\
\hline
\end{tabular}

Table 17. Estimated rate of release of immobilized nitrogen per half a week at various time intervals, following addition of either glucose and $\left(\mathrm{NH}_{4}\right)_{2} \mathrm{SO}_{4}$ or glucose and $\mathrm{NaNO}_{3}$ to HnoF soil.

( $\mathrm{mg} \mathrm{N} / 100 \mathrm{~g}$ dry soil/half week)

\begin{tabular}{|c|c|c|c|c|c|}
\hline \multirow{2}{*}{$\mathrm{C} / \mathrm{N}$} & \multicolumn{5}{|c|}{ Incubation period (weeks) } \\
\hline & 1 & 2 & 4 & 8 & 12 \\
\hline $\begin{array}{r}2 \\
4 \\
8 \\
16\end{array}$ & $\begin{array}{l}0.52 \\
0.67 \\
0.42 \\
0.83\end{array}$ & $\begin{array}{l}0.08 \\
0.24 \\
1.04\end{array}$ & $\begin{array}{c}\left(\mathrm{NH}_{4}\right)_{2} \mathrm{~S} \\
0.26 \\
0.34 \\
0.50\end{array}$ & $\begin{array}{r}-0.06 \\
-00.08 \\
0.22\end{array}$ & $\begin{array}{r}0.03 \\
0.02 \\
--0.04 \\
0.02\end{array}$ \\
\hline $\begin{array}{r}2 \\
4 \\
8 \\
16\end{array}$ & $\begin{array}{l}0.04 \\
0.55 \\
0.42 \\
1.01\end{array}$ & $\begin{array}{r}0.18 \\
-0.29 \\
0.66 \\
0.46\end{array}$ & $\begin{array}{c}\text { NaNO } \\
-0.03 \\
0.19 \\
0.09 \\
0.15\end{array}$ & $\begin{array}{l}0.06 \\
0.17 \\
0.07 \\
0.25\end{array}$ & $\begin{array}{r}\mathbf{0 . 0 1} \\
-0.04 \\
0.03 \\
0.02\end{array}$ \\
\hline
\end{tabular}

in this work will be concluded as follows:

(a) Immobilization of nitrogen in the soils receiving glucose and mineral nitrogen as either ammonium sulfate or sodium nitrate at different levels of $\mathrm{C} / \mathrm{N}$ ratio proceeded rapidly and reached its maximum on a 3-day incubation irrespective of the forms of nitrogen added and the levels of $\mathrm{C} / \mathrm{N}$ ratio treated. The amount of the nitrogen immobilized increased with increasing $\mathrm{C} / \mathrm{N}$ ratio independent of the forms of nitrogen added. These tendencies support the findings of Winsor et al. (1956), Allison et al. (1960) and Harada et al. (1968). Figures for the quantity of a maximum-immobilized nitrogen at a given $\mathrm{C} / \mathrm{N}$ ratio in each soil was a little larger in the form of ammonia than in the form of nitrate. From this result, it is likely that the soil microorganisms concerned in immobilization of nitrogen prefer ammonia rather to nitrate, as pointed out by several 
investigators (Richards et al. 1935, Winsor 1956, Jansson 1958, Broadbent et al. 1962). Comparison between the maximum immobilization of nitrogen at the $\mathrm{C} / \mathrm{N}$ ratios of 4,8 and 16 of the lowland soils and that at the corresponding $\mathrm{C} / \mathrm{N}$ ratios of the highland soils led to a result that lowland soils might be better in respect of immobilization of nitrogen in soils receiving glucose and mineral nitrogen than highland soils.

(b) Next, immediately after reaching a maximum immobilization of nitrogen in soil release of nitrogen occurred and increased with the period of incubation, the increase being probably due to mineralization of a part of the nitrogen originally immobilized in soil. The amounts of released nitrogen increased with increasing amounts of immobilized nitrogen, and the rate of release of immobilized nitrogen per half a week in each soil was largest immediately after reaching a maximum immobilization of nitrogen in all the $\mathrm{C} / \mathrm{N}$ ratios and the forms of nitrogen added. The rate was faster at an early period of incubation than at a late period of incubation. Table 18 gives the ratios of the nitrogen released for 12-week incubation to the nitrogen immobilized for 3-day incubation on which immobilization of nitrogen in each soil reached its maximum. The data showed that when the amount of nitrogen released at a given $\mathrm{C} / \mathrm{N}$ ratio was expressed as percentage of the maximum-immobilized nitrogen at a corresponding $\mathrm{C} / \mathrm{N}$ ratio, the percentage was higher in the form of nitrate than in the form of ammonia. This experimental result will be caused by the changing of $\mathrm{pH}$ in the soil after reaching a maximum immobilization of nitrogen added in the forms of either ammonia or nitrate, i. e., the increase in $\mathrm{pH}$ accompanying the immobilization of sodium nitrate- $\mathrm{N}$ and the fall in $\mathrm{pH}$ accompanying the immobilization of ammo-

Table 18. Ratio of the nitrogen released for 12 -week incubation to the maximumimmobilized N.

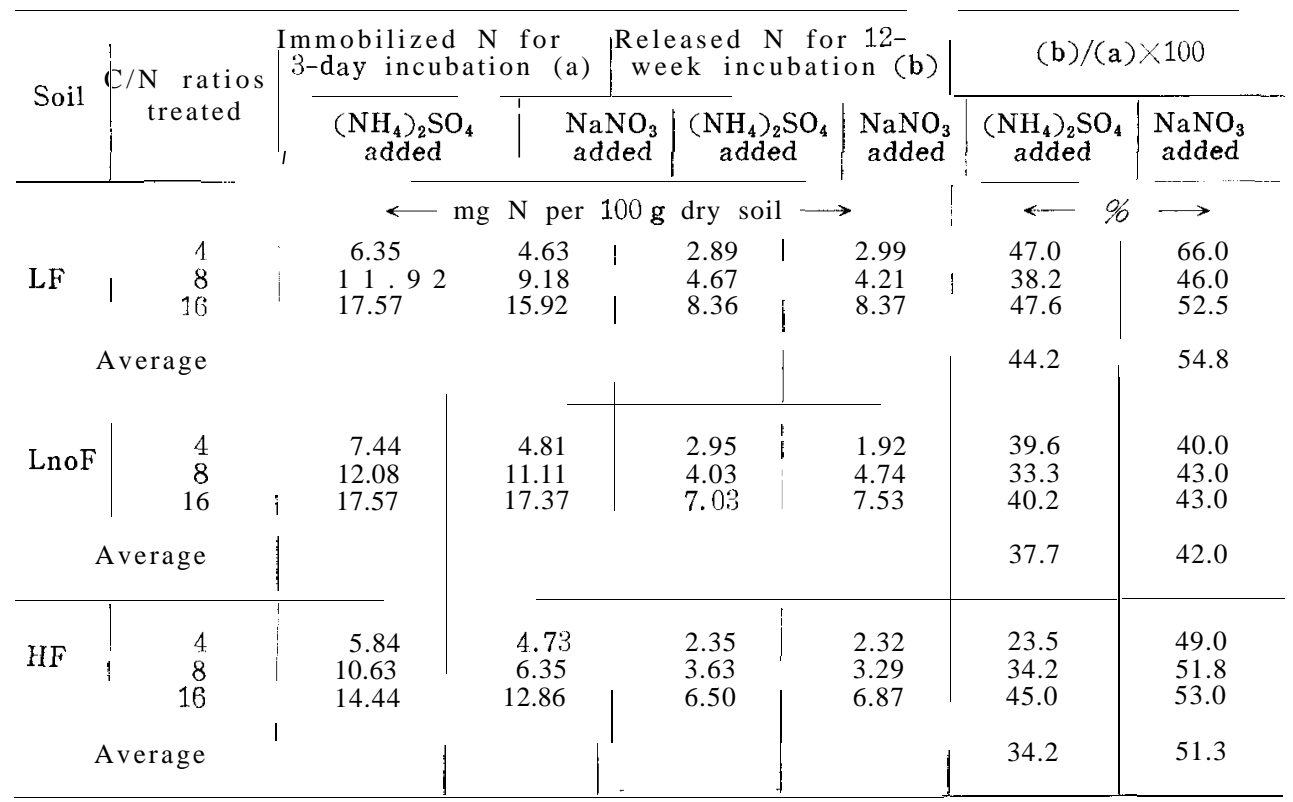


'Table 19. Changes of soil $\mathrm{pH}^{*}$ during the each interval of incubation period following addition of mineral nitrogen as $\left(\mathrm{NH}_{4}\right)_{2} \mathrm{SO}_{4}$ or $\mathrm{NaNO}_{3}$ and glucose to $\mathrm{HF}$ soil.

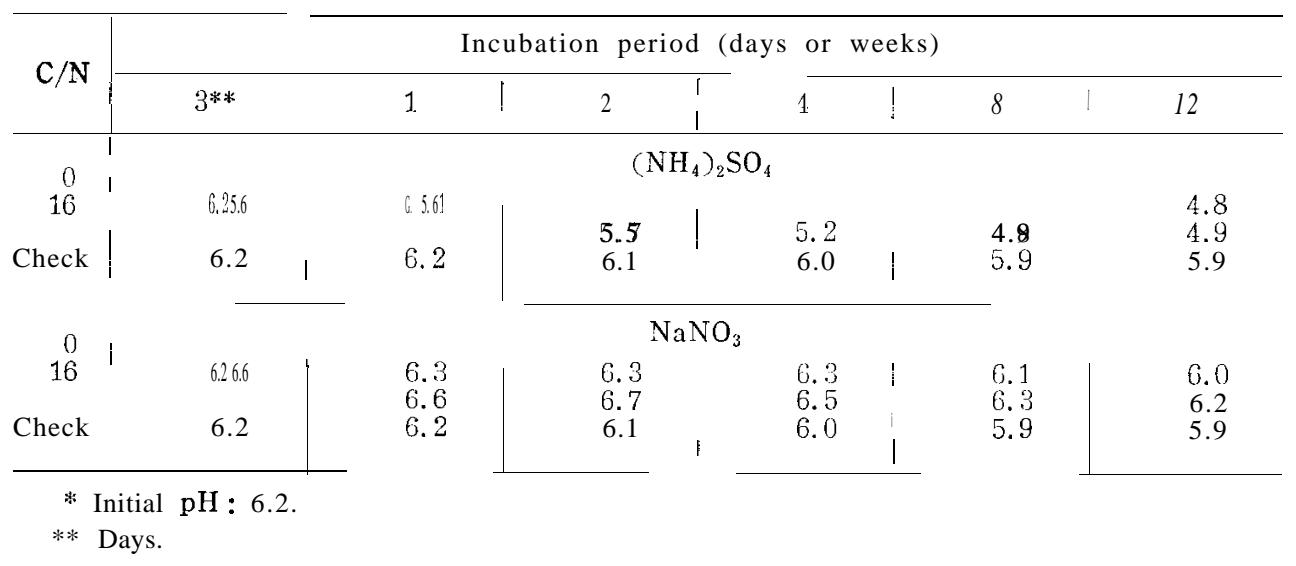

nium sulfate-N (see Table 19).

(c) Finally, the numerical relationship between carbon initially added to soil and nitrogen immobilized which was proposed by Winsor (1958) is of particularly interest when immobilization of nitrogen reaches its maximum, this being attained on incubation of approximately three days under the experimental condition used in this experiment. Therefore, ratio of carbon added initially to nitrogen immobilized for 3-day incubation was given in Table 20. The data led

Table 20. Ratio of carbon added initially to nitrogen immobilized on incubation for three days.

\begin{tabular}{|c|c|c|c|c|c|}
\hline \multirow{3}{*}{ Soil } & \multirow{2}{*}{$\begin{array}{c}\text { Carbon added } \\
\text { (a) }\end{array}$} & \multicolumn{2}{|c|}{$\begin{array}{l}\text { Nitrogen immobilized for S-day } \\
\text { incubation (b) }\end{array}$} & \multicolumn{2}{|c|}{$(\mathrm{a}) /(\mathrm{b})$ ratios } \\
\hline & & $\begin{array}{c}\left(\mathrm{NH}_{4}\right)_{2} \mathrm{SO}_{4} \\
\text { added }\end{array}$ & $\begin{array}{l}\mathrm{NaNO}_{3} \\
\text { added }\end{array}$ & $\begin{array}{c}\left(\mathrm{NH}_{4}\right)_{2} \mathrm{SO}_{4} \\
\text { added }\end{array}$ & $\begin{array}{l}\mathrm{NaNO}_{3} \\
\text { added }\end{array}$ \\
\hline & $\begin{array}{c}\mathrm{mg} \mathrm{C} \text { per } \\
100 \mathrm{~g} \text { dry s o i }\end{array}$ & $\begin{array}{ll}\operatorname{mg} & \mathrm{N} \\
100 & \mathrm{~g}\end{array}$ & $\begin{array}{l}\text { per } \\
\text { dry soil }\end{array}$ & 1 & \\
\hline LF & $\begin{array}{r}40 \\
80 \\
160 \\
320\end{array}$ & $\begin{array}{r}3.32 \\
6.15 \\
11.92 \\
17.57\end{array}$ & $\begin{array}{r}3.31 \\
4.63 \\
9.18 \\
15.92\end{array}$ & $\begin{array}{l}13.6 \\
14.6 \\
13.4 \\
38.2\end{array}$ & $\begin{array}{l}12.1 \\
17.2 \\
17.4 \\
" 0.1\end{array}$ \\
\hline LnoF & $\begin{array}{r}40 \\
80 \\
160 \\
320\end{array}$ & $\begin{array}{r}5.67 \\
7.44 \\
12.08 \\
17.57\end{array}$ & $\begin{array}{r}2.39 \\
4.81 \\
11.11 \\
17.37\end{array}$ & $\begin{array}{l}11.7 \\
10.8 \\
13.3 \\
18.1\end{array}$ & $\begin{array}{l}16.7 \\
1.6 . \mathrm{G} \\
14.4 \\
18.4\end{array}$ \\
\hline $\mathrm{HF}$ & $\begin{array}{r}40 \\
80 \\
160 \\
320\end{array}$ & $\begin{array}{c}2.98 \\
5.84 \\
10.63 \\
14.44\end{array}$ & $\begin{array}{r}2.73 \\
4.73 \\
6.35 \\
12.86\end{array}$ & $\begin{array}{l}13.4 \\
13.7 \\
15.1 \\
22.0\end{array}$ & $\begin{array}{l}14.7 \\
16.9 \\
25.2 \\
24.8\end{array}$ \\
\hline HnoF & $\begin{array}{r}80 \\
160 \\
320\end{array}$ & $\begin{array}{r}3.40 \\
6.05 \\
9.36 \\
14.19\end{array}$ & $\begin{array}{r}2.34 \\
4.12 \\
7.90 \\
11.44\end{array}$ & $\begin{array}{l}11.6 \\
13.4 \\
17.1 \\
22.7\end{array}$ & $\begin{array}{l}16.7 \\
16.8 \\
19.1 \\
25.4\end{array}$ \\
\hline
\end{tabular}


to results that the amount of carbon which must be added to the soil in order to immobilize one unit of nitrogen into organic form ranged from 11 to 25 units, increasing with the increasing carbon added initially, and it was larger in the form of nitrate than in the form of ammonia at a given $\mathrm{C} / \mathrm{N}$ ratio of all the soils used. These results were different from the findings of Winsor et al. by which there was little difference between in the form of nitrate and in that of ammonia.

\section{CONCLUSIONS}

The effect of nitrogenous forms on immobilization and release of nitrogen following addition of glucose and mineral nitrogen to soils was studied. Principal experimental results obtained revealed the following facts :

1) Immobilization of nitrogen in soils receiving glucose and mineral nitrogen as ammonium sulfate or sodium nitrate at different levels of $\mathrm{C} / \mathrm{N}$ ratio proceeded rapidly and reached its maximum on incubation for 3 days irrespective of the forms of nitrogen added and the levels of $\mathrm{C} / \mathrm{N}$ ratio treated. The amount of nitrogen immobilized increased with increasing $\mathrm{C} / \mathrm{N}$ ratio independent of the forms of nitrogen added. The nitrogen immobilized to a maximum at a given $\mathrm{C} / \mathrm{N}$ ratio was a little larger in the form of ammonia than in the form of nitrate.

2) Immediately after reaching maximum immobilization of nitrogen release of nitrogen occurred and increased with the period of incubation, the increase being probably due to mineralization of part of the nitrogen originally immobilized. The rate of release of nitrogen was faster at the early period of incubation than at the late period of incubation. When the amount of nitrogen released at a given $\mathrm{C} / \mathrm{N}$ ratio was expressed as percentage of the maximum-immobilized nitrogen at a coresponding $\mathrm{C} / \mathrm{N}$ ratios, the percentage was higher in the form of nitrate than in the form of ammonia. This result might be caused by the changing of $\mathrm{pH}$ in the soil after reaching a maximum immobilization of nitrogen added in the forms of either ammonia-N or nitrate-N.

3) The amount of carbon which must be added to the soil in order to immobilize one unit of nitrogen into organic form increased with the increasing carbon added initially and it was larger in the form of nitrate than in the form of ammonia at a given $\mathrm{C} / \mathrm{N}$ ratio of all the soils used.

Note: This paper is a part of the work entitled "Factors affecting immobilization and release of nitrogen in soil and chemical characteristics of the nitrogen newly immobilized".

\section{REFERENCES}

Ahmad, Z., Kai, H. anti Harada, T., 1969. Factors affecting immobilization and release of nitrogen in soil and chemical characteristics of the nitrogen newly immobilized. II. Effect of carbon sources on immobilization and release of nitrogen in soil. Soil Sci. Plant Nutr. (Tokyo), 15: 252-258.

Allison, F. E., 1927. Nitrate assimilation by soil microorganisms in relation to available energy supply. Soil Sci., 24: 79-92. 
Allison, F. E. and Cover, R. G., 1960. Rate of decomposition of shortleaf pine sawdust in soil at various levels of nitrogen and lime. Soil Sci., 89: 194-201.

— and Klein, C. J., 1962. Rate of immobilization and release of nitrogen following additions of carbonaceous materials and nitrogen to soils. Soil Sci., 93 : 383-386.

Bremner, J. M. and Shaw, K., 1955. Determination of ammonia and nitrate in soil. J. Agr. Sci., $46: 320-328$.

Broadbent, F. E. and Tyler, K. B., 1962. Laboratory and greenhouse investigations of nitrogen immobilization. Soil Sci. Soc. Am. Proc., 26 : 459-462.

Harada, T. and Hayashi, R., 1968. Studies on the organic nitrogen becoming decomposable through the effect of drying a soil, Soil Sci. Plant Nutr. (Tokyo), 14: 13-19.

Jansson, S. L., 1955. Orientierende Studien über den Stickstoffkreislauf im Boden mit Hilfe von ${ }^{15} \mathrm{~N}$ als Leitisotop. Z. Pflanz. ernähr.Ding. Bodenk., 69: 19]-198.

- 1958. Tracer studies on nitrogen transformation in soil with special attention to mineralization-immobilization relationships. K. LantbrHögsk. Ann., 24: 101-361.

- Hallam, M. J. and Bartholomew, W. V., 1955. Preferential utilization of ammonium over nitrate by microorganisms in the decomposition of oat straw. Plant \& Soil, 6: 382 390.

Kai, H., 1961. Determination of nitrate by a modified Conway microdiffusion analysis using Devarda's alloy as a reducing reagent. Abs. 1961 Ann. Meeting Soc. Sci. Soil Manure, Japan, No. 7: 120 (in Japanese).

- Ahmad, Z. and Harada, T., 1969. Immobilization and release of nitrogen in soil and chemical characteristics of the nitrogen newly immobilized. I. Effect of temperature on immobilization and release of nitrogen in soil. Soil Sci. Plant Nutr. (Tokyo), 15: $207-213$

Norman, A. G., 1931. The biological decomposition of plant material. IV. The activties on straws of some cellulose decomposing fungi. Ann. Appl. Biol., 18: 244-259.

Richards, E. H. and Shrikhande, J. G., 1935. The preferential utilization of different forms of inorganic nitrogen in the decomposition of plant materials. Soil Sci., 39: $1-8$.

Walunjkar, W. G. Bartholomew, W. H. and Woltz. W., 1959. Nitrogen interchange in soil as affected by soil type, source and rate of nitrogen addition, moisture, and time of incubation. J. Indian Soc. Soil Sci., 7: 65-72.

Winsor, G. W., 1958. Mineralization and immobilization of nitrogen in soil. J. Sci, Food Agr., $9: 792-801$.

— and Pollard, A. G., 1956. Carbon-nitrogen relationships in soil. I. The immobilization of nitrogen in the presence of carbon compounds. J. Sci. Food Agr., 7: 134-141. 